\title{
Peter Kemp
}

\section{Etiske princippers genkomst i omsorg for sundhed}

Det siger sig selv, at spørgsmålet om det gode liv altid har været centralt $\mathrm{i}$ menneskets overvejelser over tilværelsen. Men overvejelserne over etikken har haft forskellige forudsætninger gennem tiderne. Således er der stor forskel på den debat om etik, der foregik her i landet for 50 år siden og den debat der er foregået i de sidste 20 år.

I 1950 drejede det største spørgsmål sig om forholdet mellem etik og kristendom. Sammenvævningen af kirke og stat betød indtil da stadig for mange, at etikken måtte begrundes med den kristne livsopfattelse. Derfor vakte det stor opsigt, at en teologisk professor, K. E. Løgstrup, udsendte en bog, hvori han hævdede, at etikken kunne begrundes "rent humant".

En "rent human" opfattelse var fra Løgstrups side ment som en opfattelse, der var religiøst-metafysisk uden at være specielt kristelig. Men mange opfattede ikke denne løsrivelse af etikken fra kirke og kristendom på samme måde. Løsrivelsen blev signalet til at det nu var overladt til den enkelte selv at finde på, hvordan han eller hun fra sag til sag ville begrunde gyldigheden af etik og moral. Det var en pragmatisme, der var nært forbundet med en etisk relativisme, hvorefter enhver idé om godt og ondt kunne være lige så god som enhver anden. Etik blev noget rent individuelt, og man gik ud fra at alle forsøg på at skabe enighed om etiske spørgsmål var dømt til at mislykkes.

Denne relativisme gik hånd $\mathrm{i}$ hånd med en videnskabelig $\mathrm{og}$ teknologisk absolutisme, hvorefter den videnskabelige, teknologiske og markedsøkonomiske udvikling styrede sig selv hen imod et stadig bedre samfund, kun midlertidigt bremset af kommunismens forældede økonomiske statsøkonomi.

I denne situation blev enhver tale om etiske principper opfattet som helt ude af trit med samfundsudviklingen. Hvis der stadig kunne tales om etiske spørgsmål måtte de løses rent pragmatisk, dvs. afgøres af hvad den enkelte kunne finde på i den givne situation, og ikke med henvisning til alment gyldige principper. 
I dag kan man roligt sige, at situationen har ændret sig. Det er blevet muligt at tale om etiske principper, der kan give rammerne for de moralske afgørelser. Det er de nye teknologiske muligheder for kunstig befrugtning og for indgreb i det levendes celler og gener, der har krævet andet og mere end afgørelser fra sag til sag. Flere medicinske forskere ønskede at vide, hvad de kunne tillade sig uden at komme i konflikt med alment accepterede etiske standarder, og politikerne blev afkrævet synspunkter på, hvad der kunne være etiske acceptabelt og hvad der ikke kunne være det.

Vendingen $\mathrm{i}$ den etiske debat kan dateres temmelig præcist til efteråret 1983. I Danmark afholdtes den 4. november dette år det første paneldebat i statsligt regi om indgreb i startfasen af menneskeligt liv. Det var daværende indenrigsminister, Britta Schall Holberg, der som ansvarlig for sundhedsområdet tog initiativ til dette møde, som foregik på Rigshospitalet. Læger, biologer, en enkelt filosof og forskellige politikere diskuterede her "Etiske sider af gensplejsnings-, ægtransplantations-, fosterundersøgelsesog inseminationsteknikken" (den lange titel afslører usikkerheden om hvad man skulle kalde en etik, der vedrører disse områder). Denne diskussion var optakten til nedsættelse af et udvalg i foråret 1984 med Ulrich Horst Petersen som formand og ellers bestående af læger og jurister "om etiske problemer ved ægtransplantation, kunstig befrugtning og fosterdiagnostik": Resultatet af dette udvalgs arbejde blev rapporten fra samme år Fremskridtets pris, der anbefalede oprettelsen af et etisk råd vedrørende etiske problemer indenfor sundhedsvæsenet. Tre år senere blev et sådant råd oprettet ved lov.

Derefter fulgte nedsættelsen i 1988 af et udvalg om retslig regulering af biomedicinsk forskning på mennesker, også med Ulrich Horst Petersen som formand, og det foreslog i 1989 i rapporten Forskning på mennesket en regulering ved lov af det videnskabsetiske system, der hidtil på frivillig basis havde været den medicinske verdens selvjustits $i$ forholdet til medicinske eksperimenter med mennesker. Tre år senere vedtog Folketinget en lov, der gjorde det videnskabsetiske system til et statsligt foretagende og indførte et stærkt "lægmandselement" i systemet på alle niveauer.

Hvad der skete i Danmark var ikke en isoleret hændelse. I Frankrig var efteråret 1983 også skelsættende, idet den "rådgivende nationale etiske komité for livsvidenskaberne og sundheden" havde sit første møde, som blev åbnet af præsident François Mitterand, den 2. december 1983, hvor han udtalte disse mindeværdige ord: "Vi har gennem nogen tid troet, at en ufejlbarlig og udogmatisk fornuft ville være en tilstrækkelig vejleder for os, men nu er selve videnskabens succes i færd med at give os uret. Moderne lægevidenskab og biologi søger efter grunde dertil - men den blotte fornuft (la seule raison) kan ikke altid finde disse grunde (raisons)". 
Hjertet har sine grunde, som fornuften ikke kender, sagde allerede Pascal. Men sådanne grunde er bestemmende for vores tænkning og handling; de er principper for beslutninger og som sådanne bliver de grundlag for en praktisk rationalitet. Hvis det blot var overladt til den enkeltes forgodtbefindende at tage stilling til de etiske spørgsmål, som livs- og sundhedsvidenskaberne rejser, ville man ikke kunne tale om principper for holdningen til disse spørgsmål og det ville være meningsløst at sætte folk sammen for at forsøge at finde en enighed om holdningen.

Oprettelsen af etiske råd og komiteer forudsætter imidlertid at det er umagen værd at diskutere spørgsmålene og at der kan findes enighed på nogle væsentlige principper.

Men den etiske pragmatisme og relativisme er sejlivet. Sejlivet som illusion. For at illustrere og konkretisere denne sejlivethed, kan jeg berette om to erfaringer fra forskernes verden. I begge tilfælde mødtes forskere fra medicinske, juridiske, sociologiske og filosofiske forskningsmiljøer og var som udgangspunkt overbeviste om, at de med hensyn til etik og moral ikke kunne blive enige om noget som helst. For etikken var noget rent "subjektivt". Ikke desto mindre blev der i begge tilfælde opnået meget stor enighed om etiske principper.

Den første historie handler om forløbet af et medicinsk-etisk projekt om "de etiske grundprincipper i bioetik og bioret", som jeg fik midler til at koordinere indenfor rammerne af Europakommissionens BIOMED II program. Projektet startede i december 1995 med en snes europæiske partnere, dvs. centre eller institutter, der arbejdede med bioetik og mere eller mindre med bioret. Her var netop etiske principper selve emnet for projektet. Dets titel dxkkede over en undersøgelse af gyldighed og grænser for princippet om respekt for ethvert menneskes autonomi (selvbestemmelse) som beskyttelse af den enkelte i medicinsk og biologiske forskning. Udgangspunkter var en konstatering af, at dette autonomiprincip ikke var en tilstrækkelig beskyttelse af det menneske, der indgår i medicinske forsøg. Man kunne således ikke antage, at forsøgspersonens mulighed for at give et såkaldt informeret samtykke til at indgå i et forsøg var en tilstrækkelig beskyttelse af denne person. En række forskellige mennesker ville slet ikke være i stand til at forstå informationen om det forsøg, de skulle indgå i, f.eks. nyfødte og mindre børn, ældre og senile gamle, mentalt handikappede osv. Andre ville have svært ved det, ikke blot fordi forsøgets risici kan være svære at overskue for en ikke-fagperson, men også fordi mennesker, der er ramt af alvorlig sygdom, simpelthen ikke har kræfter til at overskue og tage stilling til problematikken i forsøget. Hensigten var så at finde frem til andre og supplerende etiske grundprincipper, man kan henvise til, når autonomiprincippet kommer til kort. 
Ud over forskellige møder mellem enkelte partnere i det europæiske projekt holdt vi fire møder for alle deltagerne. Det sidste af disse møder var det afgørende, for der skulle det afklares, om gruppen kunne blive enig om en fælles holdning til problematikken. Mødet blev holdt på Borja Instituttet for Bioetik nær ved Barcelona. På grund af en flyforsinkelse nåede jeg ikke selv frem til begyndelsen af mødet, men kom først efter at deltagerne havde diskuteret et par timer. De var vildt uenige da jeg ankom. Men jeg foreslog at vi begyndte helt forfra med hver enkelt partners præsentation af sine overvejelser over sin holdning til projektet og hvad han eller hun mente at kunne bidrage med.

Vi havde på forhånd delt arbejdet op i udarbejdelse af en stor rapport og forsøget på at formulere en fælles erklæring. Rapporten skulle dels bestå af et bind skrevet af projektets rapporteur Jacob Rendtorff sammen med mig, dels et bind med andre bidrag fra deltagerne. Denne rapport ville jeg ikke forsøge at skaffe enighed om, eftersom det bind, vi lagde op til, nærmede sig 400 trykte sider, og eftersom andre opfattelser kunne formuleres i andet bind af rapporten. Vi nøjedes derfor med at diskutere hvilke ændringer de forskellige kunne ønske i det foreløbige udkast til rapporten.

Men jeg foreslog at vi forsøgte at skabe enighed om en fælles erklæring om grundprincipperne. Desuden gjorde jeg de andre partnere opmærksomme på, at hvis vi ikke blev enige om noget, ville al opmærksomheden samle sig om den rapport, som Rendtorff og jeg havde skrevet. Måske var det dette lille skub, der fik alle til med stor energi at arbejde for at opnå enighed om formuleringen af nogle "Policy Proposals" til Europakommissionen om de etiske grundprincipper i bioetik og bioret. hvor fire etiske principper - for henholdsvis respekt for autonomi, værdighed, integritet og sårbarhed - blev formuleret og indsat $\mathrm{i}$ en kontekst af solidaritet, ansvarlighed og retfærdighed. Det lykkedes os at blive enig om en relativt udførlig tekst, der indgående beskrev de fire etiske principper for bioetik og bioret - d.v.s. respekt for autonomi, værdighed, integritet og sårbarhed - og præciserede den "omsorgsetik", som de tilhørte. Da hver enkelt partner havde konsulteret sit bagland fik vi tilslutning fra 16 partnere, dvs. så godt som alle der havde været aktive $i$ arbejdet ${ }^{1}$.

Erklæringen blev i rapporten til EU-kommissionen kaldt Barcelonaerklæringen og vi udsendte den som selvstændig folder på engelsk og fransk til biotiske centre og institutter verden over.

Pragmatismen og relativismen havde vist sig som en illusion, der måtte vige for den indsigt at når mennesker konfronteres med etiske spørgsmål er der ikke 117 forskellige meninger om alting. Mange detaljer vil der altid være uenighed om og mange spørgsmål kan trænge til yderligere afklaring, men der kan - $\mathrm{i}$ hvert fald indenfor en bestemt kultur som vores - opnås enighed 
om de store etiske retningslinjer for handling og behandling i forhold til det levende.

Den anden historie handler om et udvalgsarbejde, som jeg deltog i, og hvis sekretariat Center for Etik og Ret bistod på forskellig vis. Udvalget blev nedsat under Erhvervsministeriet i 1997 med departementschef Jørgen Rosted som formand og fik til opgave at bidrage til en nuanceret debat om bio- og genteknologiernes anvendelse, især på fødevareområdet. Medlemmerne af denne såkaldte BioTIK-gruppe var læger, biologer, filosoffer, samfunds- og sundhedsforskere. Som noget ret nyt var focus ikke kun sat på det medicinske område i snæver forstand, men på hele det område, hvor genteknologi kan påvirke sundheden for levende væsner og dermed med inddragelse af overvejelser over planters og dyrs velfærd.

Også I dette tilfælde startede diskussionen med at de fleste erklærede, at man ikke ville kunne blive enige om nogen som helst fælles etik. Men også i dette tilfælde blev denne skepsis gjort til skamme. Personligt havde jeg ved BioTIK-udvalgets start endnu ikke fået den opmuntrende erfaring fra afslutningen af det omtalte EU-projekt, og selvom jeg gerne så en enighed om principielle etiske regler formuleret, var jeg til at begynde med overbevist om, at den aldrig ville kunne realiseres. Vi kunne måske nå til enighed om nogle pragmatiske overvejelser, men hvis jeg begyndte at ville diskutere etiske kriterier for bioteknologierne, var jeg overbevist om, at vi ville ryge i totterne på hinanden.

Imidlertid var sekretariatet stødt på en udenlandsk principformulering, og denne ønskede Jørgen Rosted, vi skulle diskutere. I udvalget blev vi hurtigt enige om, at den kunne vi ikke bruge, men hvad så med at lave en bedre? Jeg tænkte, det går aldrig godt, men vi prøvede, og resultatet blev de »Etiske kriterier for udvikling og anvendelse af genteknologi« der indgår i den rapport om »De genteknologiske valg«, der blev udsendt i juni 1999 og kort efter oversat til bade engelsk og fransk ${ }^{2}$.

De etiske kriterier, vi blev enige om for udvikling og anvendelse af bioteknologi, kan sammenfattes således:

I. Hvis genteknologi skal accepteres, skal den ligesom bioteknologi i det hele taget udvikles og anvendes,

(1) til gavn for mennesket, samfundet og den levende natur, idet man fremmer livskvalitet (kvalitativ gavn) fremfor ren kvantitativ (økonomisk) gavn,

(2) med respekt for menneskets selvbestemmelsesret og værdighed,

(3) med respekt for det levendes integritet (livssammenhæng),

(4) med respekt for det levendes sårbarhed, 
(5) for at fremme retfærdighed (rimelighed) i fordelingen mellem mennesker af goder og af byrder (henholdsvis f.eks. fødevarer og alment acceptable risici),

(6) med respekt for de enkelte samfunds selvbestemmelsesret og valgfrihed idet beslutninger afspejler bekymringer og ønsker hos befolkningen, II. Genteknologien må ikke påføre mennesker uacceptable risici og forringe livet,

III. Genteknologi må ikke forringe livet for dyr,

IV. Genteknologien må ikke skade miljøet eller mindske naturens almindelige bæredygtighed,

V. Demokratisk debat og beslutning om anvendelse af genteknologi skal

(1) bygge på åbenhed for alle synspunkter forud for hver beslutning.

(2) respektere det enkelte menneskes selvbestemmelsesret

(3) vurdere og prioritere teknologier og deres anvendelse.

Ved præsentationen af rapporten udtalte forbrugerrådets daværende formand, Kirsten Nielsen, at oplægget til etiske kriterier var formuleret så vi alle sammen kan være enige. Det havde hun fuldstændig ret i. Meningen var at samle bred tilslutning. Og den blev opnået både i og med at Folketinget $i$ en efterfølgende debat sluttede op om rapportens principper, men også deri, at arbejdet med de etiske principper er blevet ført videre af den regering, der tiltrådte $\mathrm{i}$ november 2001, idet man nu vil søge at opnå $\mathrm{i}$ hvert fald europæisk og måske senere international enighed om en bioetisk konvention, der formulerer etiske kriterier på plante- og fødevareområdet $i$ tråd med de kriterier, som BioTIK-gruppen har formuleret.

Endnu engang blev den etiske relativisme afsløret som en illusion. Hvad kan være den egentlige grund til det? Mon ikke den har at gøre med at vi som mennesker af kød og blod, stillet overfor bioteknologiernes enorme udfordringer til vores sårbare kropslige liv, har et fælles »anlæg for det gode« og en fælles kultur for at tolke dette anlæg, dvs. ikke er så uenige om, hvad vi vil værne om, når det kommer til stykket og nogen får held til at formulere det, vi vil.

Men har kriterierne nogen praktisk betydning? Kan de hjælpe os til at tage stilling til de helt konkrete spørgsmål? Selvfølgelig kan de det. Ganske vist kan man godt pragmatisk fortsætte med at forbyde og tillade uden at begrunde hvorfor. Men det bliver afgørelser, hvor man stemmer med fødderne og følelserne uden at have tanken med. Det betyder, at man ikke forstår hinanden, heller ikke sig selv, konflikterne bliver skarpere end nødvendigt og kan tage sig meget irrationelle ud. 
De etiske kriterier, der her er næunt for genteknologi og bioteknologi i det hele taget giver os derimod et sprog eller en tankemåde, der gør, at selvom vi er politisk uenige om enkelte sager, forstår vi modparten, når uenigheden skyldes at vi indenfor det sprog, vi er fælles om at tale, vægter etiske principper forskelligt. Men så er vi nok heller ikke så uenige endda og kan måske indenfor EU - blive enige om en fælles holdning overfor den USA-styrede genteknologiske lobby, der - med det gode eller det onde - vil have os til at spise masser af gensplejset mad fra kraftigt manipulerede planter og dyr.

Der er nu engang stor forskel på, om vi tilfældigvis er enige og uenige om forskellige ting uden at forstå hvorfor, eller om vi er mere eller mindre enige om fortolkningen af principperne om respekt selvbestemmelse, værdighed, integritet og sårbarhed, som alle imidlertid anser for væsentlige, fordi de udtrykker aspekter af vor kulturs syn på mennesket, samfundet og naturen. I det første tilfælde er vi radikalt isolerede individer uden virkeligt fællesskab, i det andet tilfælde har vi trods al uenighed et dybt rodfæstet socialt, kulturelt og historisk fællesskab.

Om den enighed om etiske principper man kan opnå i et samfund, hvor de sociale spændinger er ret små, kan overføres til at gælde for et europæisk fællesskab eller måske endda et internationalt for flere kulturer, kan vi ikke vide i dag. Men det mest frugtbare er ikke at standse der, men at arbejde i håbet om at enigheden er mulig. Og så er der nok at tage fat på. 


\section{Noter}

${ }^{1}$ The Barcelona Declaration (1998)

2 BioTIK-gruppen (1999)

\section{Litteratur}

Partners in the BIOMED-II Project Basic Ethical Principles in Bioethics and Biolaw (1998): The Barcelona Declaration, Policy Proposals to the European Commission November 1998. Erklæringen fås som folder på engelsk eller fransk fra Centre for Ethics and Law, e-mail: centre.for@ethiclaw.dk, og indgår i øvrigt i rapporten Basic Ethical Principles in European Bioethics and Biolaw, by Jacob Dahl Rendtorff and Peter Kemp, Institut Borja de Bioètica, Barcelona, and Centre for Ethics and Law, Copenhagen, 2000, Vol. I, s. 393-399.

BioTIK-gruppen, Erhvervsministeriet (1999): De genteknologiske valg, Statens Information, København; folkelig udgave (udarbejdet af Gitte Meyer) (1999): De genteknologiske valg, en genfortælling af et debatoplæg, Statens Information, Postboks 1103, fax. 33379280. København. 